УДК 551.583(477.72)

DOI https://doi.org/10.32848/agrar.innov.2021.5.3

\title{
ДИНАМІКА ЗМІНИ ТЕМПЕРАТУРНОГО РЕЖИМУ ТА КІЛЬКОСТІ ОПАДІВ У ХЕРСОНСЬКІЙ ОБЛАСТІ В КОНТЕКСТІ ЗМІН КЛІМАТУ
}

\author{
ВОЖЕГОВА Р.А. - доктор сільськогосподарських наук, професор, академік \\ Національної академії аграрних наук України \\ https://orcid.org/0000-0002-3895-5633 \\ Інститут зрошуваного землеробства Національної академії аграрних наук України
}

Постановка проблеми. Глобальне потепління $€$ однією з головних проблем, з якими людство стикається сьогодні. Зміни кліматичних умов, що спостерігаються в усіх куточках світу, мають вплив на біосферу Землі на макро- та мікрорівні. Люди відчувають вплив зміни клімату на своє здоров'я, на ведення виробничої діяльності, а також на природні ресурси та біорізноманіття, продовольчу безпеку тощо [1]. Забезпечення сталого виробництва продукції рослинництва $є$ однією з головних передумов продовольчої безпеки, тому пошук шляхів подолання негативного впливу глобальних кліматичних змін на галузь $€$ надзвичайно важливим завданням сучасної науки. Вирішення цього завдання неможливе без чіткого розуміння динаміки кліматутворюючих процесів, оскільки вивчення даних чинників надає уявлення про очікувані перспективи кліматичної ситуації та створює підґрунтя для прийняття зважених рішень у сорері трансформації виробництва продукції рослинництва з урахуванням сучасних параметрів погодних умов та рівня забезпечення природними та матеріально-технічними ресурсами.

Аналіз останніх досліджень і публікацій. Проблеми, з якими стикаються фахівці з рослинництва, ускладнюються різницею у напрямах зміни клімату в різних частинах світу. Так, Північна Європа прогнозовано зазнає збільшення кількості опадів, а от південні та східні райони страждатимуть від посилення посушливості, що пов'язано зі зростанням температури повітря за зменшення кількості опадів та нерівномірності їх розподілу в часі [2]. Нерівномірність у розподілі опадів на тлі підвищення температури повітря призведе до збільшення частоти негативних метеорологічних явищ (посух та злив), що, своєю чергою, позначиться на врожайності та якості продукції на незрошуваних масивах та землях без систем дренажу [3]. Окрім того, велике значення набуватимуть генетичні ресурси рослин, а також матеріально-технічна база агровиробників. Тому стратегії адаптації та пом'якшення наслідків, які будуть застосовуватися у секторі рослинництва, повинні враховувати відмінності у ресурсному забезпеченні, а підходи до змін місцевих аграрних екосистем повинні базуватися на реальному кліматичному стані кожного конкретного регіону та враховувати перспективи розвитку метеорологічної ситуації [4].

Мета статті. Аналіз сучасного стану температурного режиму та надходження опадів у Херсонській області України, з'ясування тенденцій подальших змін у кліматичному режимі регіону, встановлення можливих ризиків для виробництва продукції рослинництва.
Матеріали та методика досліджень. Для проведення досліджень було використано архівні метеодані Херсонської обласної гідрометеорологічної станції за період з 1905 по 2020 р. (виключаючи 1990 р. як такий, що не мав повних даних, необхідних для виконання розрахунків), а саме показники середньорічної температури повітря та річної кількості опадів. Лінійні тренди та прогнози динаміки згадуваних метеорологічних показників було здійснено за допомогою функції прогнозу Microsoft Excel 365 за алгоритмом Вінтерса [5]. Для того щоб знайти тенденцію зміни температури повітря та кількості опадів, було проведено тест Манна-Кендалла та Сена на довірчому інтервалі 95\% [6-8]. Щоб забезпечити кращу візуалізацію досліджуваних індексів, контрольні карти з розрахунком середнього значення, верхньої (UCL) і нижньої (LCL) контрольних меж були створені для кожного індексу за допомогою BioStat v7 за алгоритмом обчислення, запропонованим Пейджем [9].

Результати досліджень. Результати оцінки багаторічних даних щодо динаміки середньорічної температури повітря та кількості опадів відображено графічно (рис. 1, 2).

Результати тесту Манна-Кендалла та Сена за довірчого інтервалу 95\% виявили наявність чіткого тренду у змінах середньорічної температури повітря в Херсонській області та кількості річних опадів (табл. 1).

Побудова прогнозу розвитку кліматичної ситуації підтверджує тренди, виявлені попередньо виконаними статистичними тестами, а саме тренди до зростання середньорічної температури повітря та сумарної річної кількості опадів (табл. 2). Графічно прогнози відображено на рис. 3, 4.

Для порівняння середніх метеорологічних показників за досліджуваний період (1905-2020 рр.) із прогнозованими на період 2020-2050 рр. та комбінований проміжок часу (1905-2050 рр.) було узагальнено розрахунки в табл. 3.

Прогноз метеорологічних показників свідчить про неминучість подальшого зростання температури повітря (на 18,8\%) та кількості опадів (на 24\%) порівняно 3 періодом минулих років. Причому передбачається зростання потенційної евапотранспірації в регіоні [10], що поставить під загрозу стабільність виробництва продукції рослинництва у незрошуваних районах Херсонської області, оскільки низька рівномірність розподілу опадів та тенденція до збільшення кількості неефективних опадів зливового характеру у весняно-літній період не будуть спроможні перекрити дефіцит вологи внаслідок посилення випаровуваності та зростання температур вегетаційного періоду. 


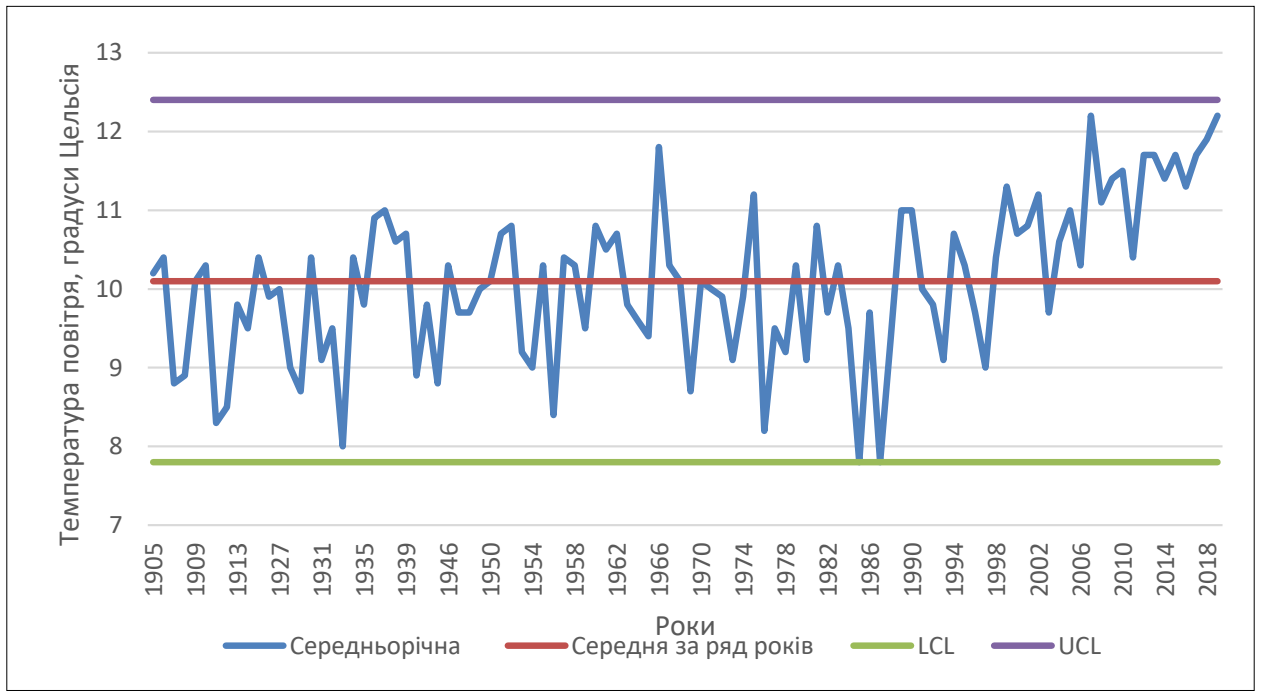

Рис. 1. Динаміка середньорічної температури повітря (період 1905-2020 рр., Херсонська область)

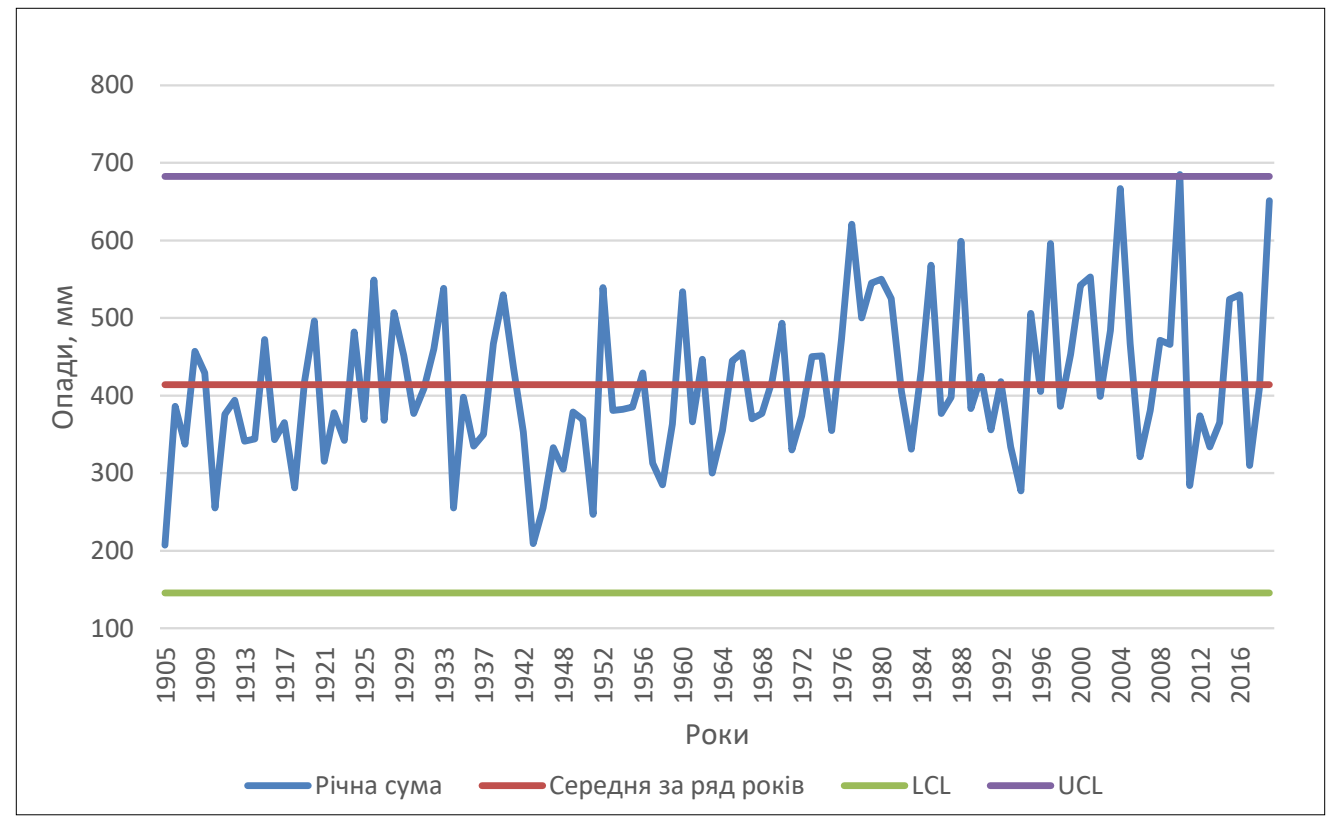

Рuc. 2. Динаміка річної кількості опадів (період 1905-2020 рр., Херсонська область)

Таблиця 1 - Результати тесту Манна-Кендалла та Сена за довірчого інтервалу $95 \%$ для динаміки середньорічної температури повітря та кількості опадів у Херсонській області за період 1905-2020 pp.

\begin{tabular}{|l|c|c|}
\hline \multicolumn{1}{|c|}{ Критерій } & $\begin{array}{c}\text { Температура } \\
\text { повітря }\end{array}$ & Кількість опадів \\
\hline S & 1624 & 1182 \\
\hline se & 345.45 & 397.67 \\
\hline Z-stat & 4.698 & 2.970 \\
\hline p-value & $2.6 \times 10^{-6}$ & 0.003 \\
\hline тренд & yes & yes \\
\hline ухил & 0.016 & 0.800 \\
\hline нижній ліміт & 0.010 & 0.275 \\
\hline верхній ліміт & 0.022 & 1.403 \\
\hline
\end{tabular}

Таблиця 2 - Результати прогнозу середньорічної температури повітря та кількості опадів у Херсонській області до 2050 р.

\begin{tabular}{|l|c|c|}
\hline \multicolumn{1}{|c|}{ Критерій } & Значення критерію \\
\cline { 2 - 3 } & $\begin{array}{c}\text { Температура } \\
\text { повітря }\end{array}$ & $\begin{array}{c}\text { Кількість } \\
\text { опадів }\end{array}$ \\
\hline Alphа (довірчий інтервал) & 0,25 & 0,25 \\
\hline $\begin{array}{l}\text { МАSE (середня абсолютна } \\
\text { зважена помилка) }\end{array}$ & 1,04 & 1,18 \\
\hline $\begin{array}{l}\text { SМАРЕ (зважена середня } \\
\text { абсолютна похибка } \\
\text { у відсотках) }\end{array}$ & 7 & 22 \\
\hline $\begin{array}{l}\text { МАЕ (середня абсолютна } \\
\text { похибка) }\end{array}$ & 0,70 & 101,89 \\
\hline $\begin{array}{l}\text { RМSE (середньоквадратична } \\
\text { помилка) }\end{array}$ & 0,91 & 119,31 \\
\hline
\end{tabular}




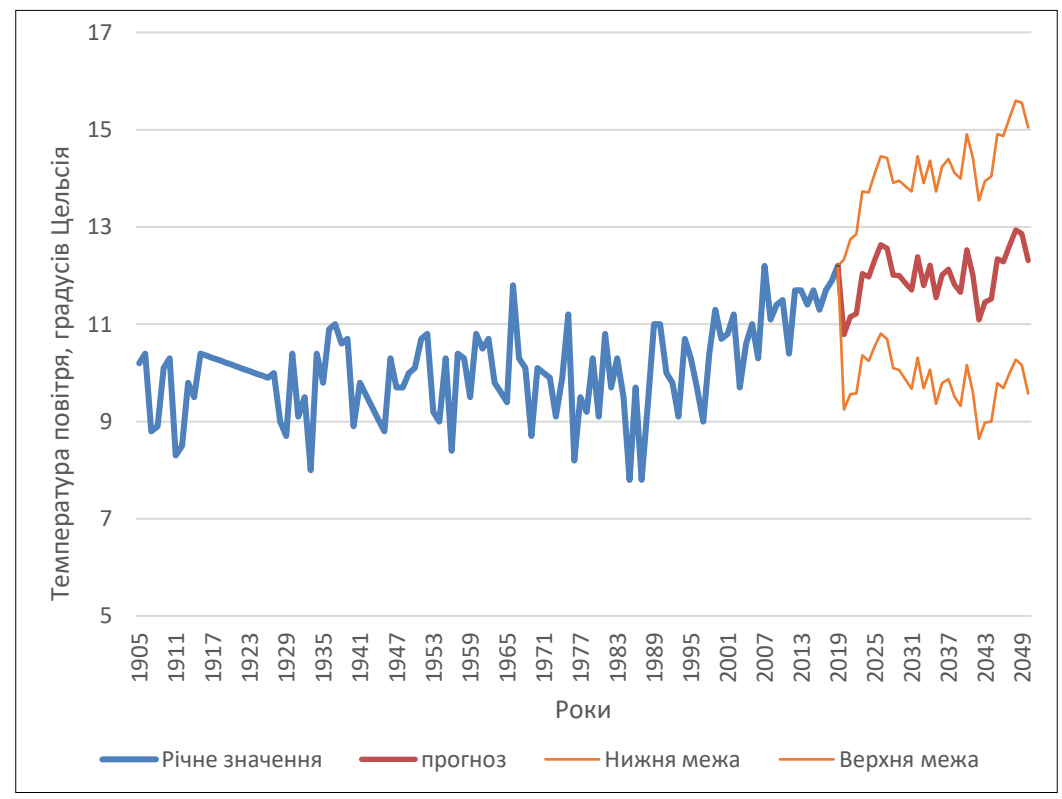

Рис. 3. Прогноз середньорічної температури повітря у Херсонській області на період до 2050 р. (точка початку прогнозу - 2020 р.)

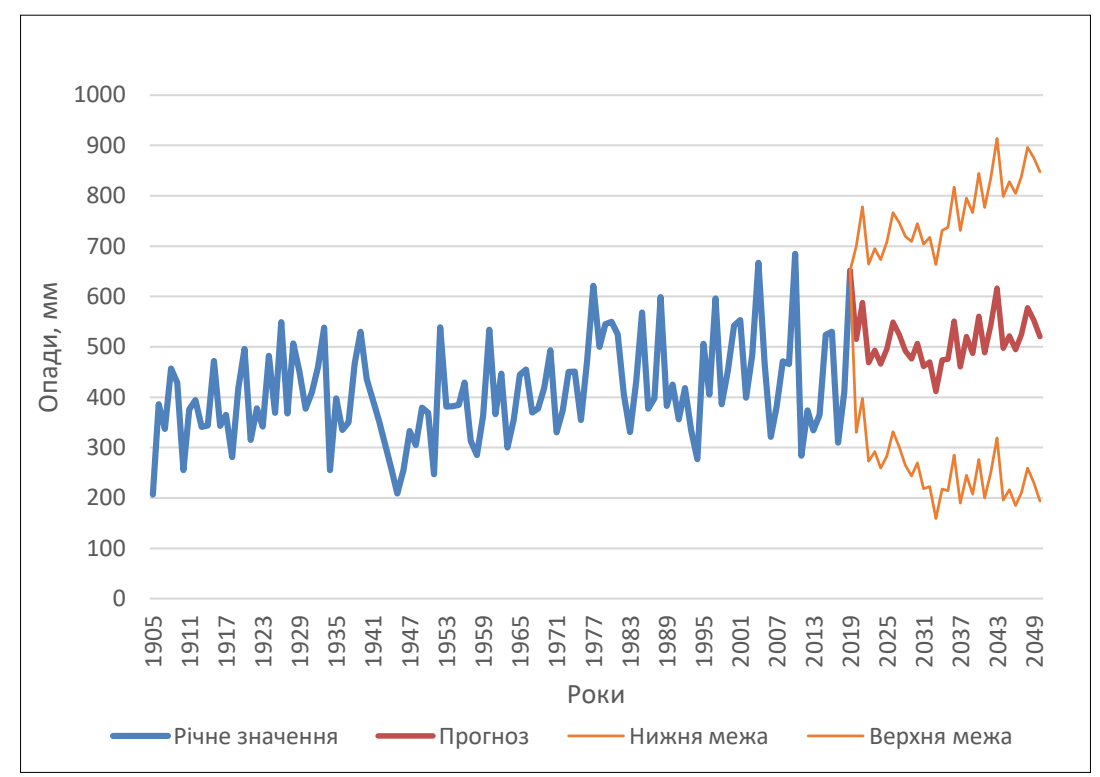

Рис. 4. Прогноз суми опадів за рік у Херсонській області на період до 2050 p. (точка початку прогнозу - 2020 р.)

Таблиця 3 - Середні значення річної температури повітря та опадів по Херсонській області для періодів 1905-2020, 2021-2050 та 1905-2050 рр.

\begin{tabular}{|c|l|l|}
\hline \multirow{2}{*}{ Період } & \multicolumn{2}{|c|}{ Метеорологічний показник } \\
\cline { 2 - 3 } & $\begin{array}{c}\text { Середньорічна } \\
\text { температура повітря }\end{array}$ & $\begin{array}{c}\text { Річна } \\
\text { сума опадів }\end{array}$ \\
\hline $1905-2020$ & 10,09 & 410,5 \\
\hline $2020-2050$ & 11,99 & 509,2 \\
\hline $1905-2050$ & 10,48 & 432,1 \\
\hline
\end{tabular}

Окрім того, поряд із переглядом стратегії зрошення та його якомога широкого впровадження в регіоні потрібно переглянути системи захисту рослин, оскільки зміни кліматичних умов стимулювати- муть прискорений розвиток шкідників, зміну їх видового складу в бік розширення, збільшення генерацій і загальної популяції шкодочинних організмів унаслідок кращої перезимівлі в умовах вологої та теплої зими, а також сприятимуть інтенсивнішому ураженню сільськогосподарських культур грибковими та вірусними захворюваннями. Перегляду підлягатиме і сортовий склад культур, а також терміни їх висівання та збирання врожаю. Комплексний підхід до вирішення проблеми сталого рослинництва в умовах змін клімату матиме успіх за раціонального та поступового вживання всіх необхідних заходів.

Висновки. Результати дослідження показали, що у Херсонській області спостерігається тенденція 
до підвищення середньорічної температури повітря. Підвищення температури повітря неминуче вестиме до збільшення потенційного випаровування. Окрім того, зростатиме очікувана кількість опадів, проте переважно за рахунок зливових опадів, що ставить під питання можливість перекриття зростаючого випаровування за рахунок природного зволоження. Зрошення стане необхідною передумовою розвитку виробництва продукції рослинництва, тому потрібно вжити заходів для реконструкції раніше побудованих та будівництва нових зрошувальних систем у Херсонській області для забезпечення продовольчої безпеки на Півдні України.

\section{СПИСОК ВИКОРИСТАНОÏ ЛІТЕРАТУРИ:}

1. Climate change and global food security / $R$. Lal et al. CRC Press, 2005. 808 p.

2. Impacts and adaptation of European crop production systems to climate change / J.E. Olesen et al. European Journal of Agronomy. 2011. Vol. 34(2). P. 96-112.

3. Яценко В.О., Хоменко І.А. Ступінь вразливості території України до зміни характеру розподілу опадів. Гідрологія, гідрохімія і гідроекологія. 2019. Вип. 3. С. 172-173.

4. Artificial croplands and natural biosystems in the conditions of climatic changes: possible problems and ways of their solving in the South Steppe Zone of Ukraine / R.A. Vozhehova et al. Research Journal of Pharmaceutical, Biological and Chemical Sciences. 2018. Vol. 9(6). P. 331-340.

5. Winters P.R. Forecasting sales by exponentially weighted moving averages. Management Science. 1960. Vol. 6(3). P. 324-342.

6. Mann H.B. Nonparametric tests against trend. Econometrica. 1945. Vol. 13. P. 245-259.

7. Kendall M.G. Rank correlation methods. London : Griffin, 1970. 210 p.

8. Gocic M., Trajkovic S. Analysis of changes in meteorological variables using Mann-Kendall and Sen's slope estimator statistical tests in Serbia. Global and Planetary Change. 2013. Vol. 100. P. 172-182.

9. Page E.S. Continuous inspection schemes. Biometrika. 1954. Vol. 41(1/2). P. 100-115.

10. Vozhehova R.A., Lykhovyd P.V., Biliaieva I.M. Aridity assessment and forecast for Kherson oblast (Ukraine) at the climate change. EurAsian Journal of BioSciences. 2020. Vol. 14. P. 1455-1462.

\section{REFERENCES:}

1. Lal, R., Uphoff, N., Stewart, B.A., \& Hansen, D.O. (Eds.). (2005). Climate change and global food security. CRC Press. [in English].

2. Olesen, J.E., Trnka, M., Kersebaum, K.C., Skjelvåg, A.O., Seguin, B., Peltonen-Sainio, P., Rossy, F., Kozyra, J., \& Micale, F. (2011). Impacts and adaptation of European crop production systems to climate change. European Journal of Agronomy, 34(2), 96-112 [in English].

3. Yatsenko, V.O., \& Khomenko, I.A. (2019). Stupin vrazlyvosti terytoriyi Ukrayiny do zminy kharakteru rozpodilu opadiv [The level of vulnerability of the territory of Ukraine to the change in rainfall distribution]. Gidrologiya, gidroximiya i gidroekologiya - Hydrology, Hydrochemistry and Hydroecology, 3, 172-173 [in Ukrainian].
4. Vozhehova, R.A., Kokovikhin, S.V., Lykhovyd, P.V., Vozhehov, S.H. \& Drobitko, A.V. (2018). Artificial croplands and natural biosystems in the conditions of climatic changes: possible problems and ways of their solving in the South Steppe Zone of Ukraine. Research Journal of Pharmaceutical, Biological and Chemical Sciences, 9(6), 331-340 [in English].

5. Winters, P.R. (1960). Forecasting sales by exponentially weighted moving averages. Management Science, 6(3), 324-342 [in English].

6. Mann, H.B. (1945). Nonparametric tests against trend. Econometrica, 13, 245-259 [in English].

7. Kendall, M.G. (1970). Rank correlation methods. Griffin, London, UK [in English].

8. Gocic, M., \& Trajkovic, S. (2013). Analysis of changes in meteorological variables using Mann-Kendall and Sen's slope estimator statistical tests in Serbia. Global and Planetary Change, 100, 172-182 [in English].

9. Page, E.S. (1954). Continuous inspection schemes. Biometrika, 41(1/2), 100-115 [in English].

10. Vozhehova, R.A., Lykhovyd, P.V., Biliaieva, I.M. (2020). Aridity assessment and forecast for Kherson oblast (Ukraine) at the climate change. EurAsian Journal of BioSciences, 14, 1455-1462 [in English].

Вожегова Р.А. Динаміка зміни температурного режиму та кількості опадів у Херсонській області в контексті змін клімату

Мета. Аналіз сучасного стану температурного режиму та надходження опадів у Херсонській області України, з'ясування тенденцій подальших змін у кліматичному режимі регіону, встановлення можливих ризиків для виробництва продукції рослинництва. Методи. Історичний метод оцінки метеорологічних показників (середньорічної температури повітря та річної суми опадів) за даними Херсонського обласного гідрометеорологічного центру; статистичні методи Манна-Кендалла та Сена для оцінки трендів у динаміці досліджуваних метеорологічних показників і формування прогнозу на майбутній період методом Вінтерса. Результати. Виявлено чіткий достовірний (на довірчому рівні 95\%) тренд до підвищення середньорічної температури повітря та суми опадів у регіоні. Прогнозовано, що середньорічна температура повітря на період 2020-2050 рр. становитиме $11,99^{\circ} \mathrm{C}$, а кількість опадів може зрости до 509,2 мм. Суттєве підвищення температури повітря поряд із нерівномірністю та зливовим характером опадів вестиме до посилення посушливості у Херсонській області, що вимагатиме вживання заходів меліоративного характеру, а також перегляду основних елементів технології вирощування сільськогосподарських культур, а саме режимів і норм зрошення, строків сівби та збирання врожаю, сортового та видового складу культур, системи захисту рослин від шкідників та хвороб. Висновки. Зрошення стане необхідною передумовою розвитку виробництва продукції рослинництва, тому потрібно вжити заходів для реконструкції раніше побудованих та будівництва нових зрошувальних систем у Херсонській області для забезпечення продовольчої безпеки на Півдні України, а також переглянути та осучаснити наявні агротехнологічні рекомендації для основних сільськогосподарських культур, вирощуваних у регіоні.

Ключові слова: зрошення, клімат, метеорологічні умови, прогноз, тренд. 
Vozhehova R.A. Dynamics of changes in air temperature and precipitation amounts in Kherson oblast in the context of climate change

Purpose. Analysis of the current state of the air temperature regime and the income of precipitation in Kherson oblast of Ukraine, clarifying the tendencies of further changes in the climatic regime of the region, establishing possible risks for the production of crop products. Methods. Historical method for assessing meteorological indices (average annual air temperature and annual precipitation amounts) according to the data of Kherson Regional Hydrometeorological Center; statistical methods of MannKendall and Sen's slope for assessing trends in the dynamics of the studied meteorological indices and the formation of a forecast for the future period using the Winters's method. Results. A clear reliable (at the 95\% confidence level) trend towards an increase in the average annual air temperature and the amount of precipitation in the region was determined. It is predicted that the average annual air temperature in the period of $2020-2050$ will increase to $11.99^{\circ} \mathrm{C}$, and the amount of precipitation might increase to $509.2 \mathrm{~mm}$. A significant increase in air temperature, together with the unevenness and shower nature of precipitation, will lead to an increase in aridity in Kherson oblast, which will require the adoption of reclamation measures, as well as a revision of the main elements of the crops cultivation technology, namely, irrigation schedules and rates, sowing and harvesting dates, varietal and species composition of crops, plant protection systems against pests and diseases. Conclusions. Irrigation will become a prerequisite for the development of crop production, therefore, it is necessary to take measures to reconstruct previously built and build new irrigation systems in Kherson oblast to ensure food security in southern Ukraine, as well as to revise and modernize the existing agrotechnological recommendations for the major crops cultivated in the region.

Key words: irrigation, climate, meteorological conditions, forecast, trend. 